\title{
Şehir içi sinyalize kavşakların yeterliliğinin tasarım kriterleri puanlama yöntemi ile belirlenmesi
}

\author{
Seda HATiPOĞLU ${ }^{1, *}$, Nuri Emre OĞUZHAN ${ }^{2}$ \\ ${ }^{1}$ Gazi Üniversitesi Trafik Planlaması ve Uygulaması Anabilim Dalı, Teknikokullar, Ankara. \\ ${ }^{2}$ Ankara Büyükşehir Belediyesi, Ankara. \\ Geliş Tarihi (Recived Date): 26.05.2017 \\ Kabul Tarihi (Accepted Date): 24.01.2018
}

\section{Özet}

Büyük kentler başta olmak üzere kentlerimizde, ulaşımın kilit noktaları olan kavşak alanlarında yaşanan zaman kayıpları ve kazalar, tüm karayolu kullanıcılarının yaşadığı olumsuzluklardır. Kavşaklardaki güvenlik eksiklikleri ve kapasite yetersizlikleri, ancak yapılacak olan düzenli ve etkin iyileştirme çalışmalart ile giderilebilecektir. Kavşak iyileştirme çalışmalarının yapılabilmesi için ilk önce kavşağın mevcut durumunun doğru ve eksiksiz olarak tespit edilmesi gereklidir. Копи ile ilgili literatür incelendiğinde, kavşak kapasitesini ya da bazı güvenlik parametrelerini tek tek inceleyen çalışmalar bulunmakla birlikte; kavşağın kapasitesini ve tüm güvenlik parametrelerini bir arada inceleyen herhangi bir çalışmaya rastlanmamıştır. Bu çalışmada; kent içi kavşaklarda, kavşak tasarımında yer alan parametrelerin bütününün, sayısal olarak değerlendirildiği ve yine sayısal olarak durumun ve eksikliklerin ortaya çıkarıldı̆̆ı bir yöntem geliştirilmiş ve bu yöntem Ankara Kentinde seçilen üç kavşağa uygulanarak sonuçları değerlendirilmiştir. Yerel yönetimlerin görev kapsamına giren kent içi kavşak düzenlemeleri uygulamaları sırasında geliştirilen bu yöntemin kullanılmasının, iyileştirme çalışmaları için önemli bir veri tabanı oluşturacağı düşünülmektedir.

Anahtar kelimeler: Kent içi kavşaklar kavşakların yeterliliği, kapasite, güvenlik.

\section{Determining qualification of urban signalized intersections with method of scoring design criteria}

\begin{abstract}
\footnotetext{
* Seda HATİPOĞLU, sedab@gazi.edu.tr, https://orcid.org/0000-0002-4511-1914

Nuri Emre OĞUZHAN, n.e.o@hotmail.com.tr, https://orcid.org/0000-0002-2787-8230
} 
In our cities, especially big cities, at the intersections that the key point area of transportation, lost time and accidents are the negativities that experienced by all road users. Lack of security and lack of capacity at intersections, it can only be resolved, through regular and effective improvements. Complete and accurate detection of current situation is necessary first to perform intersection improvements. When examining the literature about this subject, although there are many studies on intersection capacity or some safety parameters one by one; but not aware of any studies on intersection capacity and all safety parameters together In this study; has been developed a method which has works on whole design parameters of the intersections and it has quantify evaluation, situation and deficiencies. This method has applied on three intersections of Ankara City and the results were evaluated. During the urban intersection arrangement applications which is within the scope of the duty of municipalities, using this method, it is considered to be an important data base for improvement works.

Keywords: Urban intersection, sufficiency of intersection, capacity, safety.

\section{Giriş}

Trafiğe çıkan özel araç sayısının hızla artış gösterdiği günümüzde, trafikte kaybedilen can, mal ve zaman kayıpları artmakta ve yaşanan bu durum sağlı ve ekolojik açıdan tahribatlar yaratmaktadır. Bu kayıpları en aza indirmek için, doğru bir ulaşım planlaması ve trafik denetimiyle birlikte, gün geçtikçe artan trafik yoğunluğuna uygun düzenlemelerin de yapılması gerekmektedir. Ulaşım ağı şehir içi ve kent dışı olarak iki bölüme ayrıldığında her ne kadar büyük tahribatlı kayıplar kent dışında olsa da şehir içi trafik yoğunluğunun getirdiği ekonomik ve sosyal kayıplar büyük ölçüde insan hayatını etkilemektedir. Özellikle büyükşehirlerde bu olumsuzluklar günlük hayatın bir parçası olmuştur.

Bütün bir ulaşım ağı ele alındığında problemlerin yoğunlaştığı noktaların kavşak alanları olduğu ortaya çıkmaktadır. Bu sebeple kavşaklar, çözüm noktasında ele alınması öncelikli trafik unsurlarıdır. İdeal şehir içi bir kavşaktan beklenen yüksek kapasite ve üst düzey güvenliktir. Bu özellikleri sağlamak için ise kavşağı beklentileri karşılayacak şekilde tasarlamak gerekir. Kavşak tasarımı için ilgili karayolu kesiminin geometrik özellikleri hem yol kapasitesi hem de trafik güvenliği açısından büyük önem taşımaktadır [1].

Mevcut kavşakların ise günümüz teknoloji şartlarına ve sosyal hayat standartlarına uyum sağlayacak şekilde düzenlenmesi gerekmektedir. Özellikle kentlerin ana arterleri üzerinde bulunan kent ile özdeşleşmiş kavşakların işlevselliğini zamanla kaybetmiş olması kentteki günlük yaşam ve güvenlik zafiyetleri oluşturmasının yanında, kentin çehresini ve kalitesini de olumsuz etkilemektedir. Ortaya çıkabilecek bu olumsuzlukların giderilmesi ve önceden tedbir alınabilmesi amacıyla farklı şekillerde kavşak analiz yöntemleri geliştirilmiştir. $\mathrm{Bu}$ çalışmanın yapılan çalışmalardan farkı; kentteki tüm kavşakların hızlı bir şekilde değerlendirilip, yerel yönetimler için sayısal bir acil müdahale öncelik çizelgesi oluşturmuş olmasıdır. Bu çizelgede kullanılan sayısal altyapı "hızlı değerlendirme yöntemi" ile oluşturulmuştur. 
Çalışmada; kavşak kapasitesi ve kavşak güvenliği parametrelerini bütün halinde değerlendiren ve sonuçta kavşağın mevcut işlevsellik durumu ile yetersiz olduğu parametreleri sayısal olarak ortaya koyan bir "hızlı değerlendirme yöntemi" geliştirilmiştir. Geliştirilen bu yöntem Ankara Kentinde yer alan 3 adet sinyalize kavşağa uygulanmıştır. Bu kavşakların kentin merkezi bölgesinde, günlük nüfus hareketlerinin yoğun olduğu ve uzun süredir mevcut haliyle kullanılan kavşaklar olmasına dikkat edilmiştir. Geliştirilen kavşak puanlama yöntemine göre; bu kavşakların mevcut durumu sayısallaştırılarak güvenlik ve kapasite değerlendirmeleri yapılmış olup; yapılan çalışmanın genel sonuçları yorumlanmış ve Kavşak Tasarım Kriterleri Puanlama Yönteminin daha verimli kullanılabilmesi için öneriler sunulmuştur.

\section{Literatür araştırması}

Türkiye'de ve dünyada kent içi kavşaklarla ilgili yapılmış birçok çalışma bulunmaktadır. Bu çalışmaların büyük bir bölümü sürücü davranışları, sinyalizasyon düzenlemeleri, kavşak geometrisi/kavşak tipi değişiklikleri, kavşaklar arası yeşil dalga uygulanması, kavşaktaki trafik akımının kompozisyonu vb. parametreleri kullanarak kavşak kapasitesinin artırılmasına yöneliktir. Yapılan çalışmaya temel oluşturması bakımından bu çalışmaların bazıları aşağıda özetlenmiştir.

Çetin tarafından yapılan doktora tez çalışmasında, kavşak kapasitesi sürücü davranışı merkezli incelenmiştir. Çalışmada, sinyalize kavşak tasarımında kullanılması gereken temel kriterlerden biri olan doygun akımı belirlemek amacıyla yeni bir yöntem geliştirilmiştir. Geliştirilen yöntem İzmir il merkezinde yer alan farklı kavşaklarda denenmiştir. Önerilen yöntem için araç uzunluğu, araçlar arası mesafe, tepki süresi, hızlanma ivmesi, hızlanma süresi ve kavşak geçiş hızı gibi değişkenler kullanılmıştır. $\mathrm{Bu}$ değişkenlerden önemli bir bölümü sürücü davranışı ile ilgilidir. Önerilen yöntem doygun akımın belirlenmesinde ve sürücü davranışlarının doygun akıma etkisinin tespitinde olumlu sonuçlar sunmaktadır [2].

Çakıcı ve Murat tarafından yapılan çalışmada, kavşak kapasitesi sinyalizasyon ve faz sayıları odaklı ele alınmıştır. Çalışmada, sinyalize dönel kavşaklarda sinyal devre süresi ve faz planı için bir hesap yaklaşımı önerilmiştir. Tasarımın etkinliği, farklı tip kavşaklar ve farklı faz planları göz önünde bulundurularak değerlendirilmiş ve gecikme performans kriteri dikkate alınarak ölçülmüştür. Analizler sonucunda, sola dönüş oranı arttıkça, faz sayısı artışına da bağlı olarak, sinyalize dönel kavşaklar yerine, farklı alternatiflerin tercih edilebileceği bulgusuna ulaşılmıştır [3]. Yine Murat tarafından yapılan çalışmada, sinyalize kavşaklardaki ortalama taşıt gecikmelerinin tahmini amacıyla bulanık mantık tekniğinden faydalanılmıştır. Gecikme olayının doğrusal olmayan karmaşık yapısı ve belirsizlikler içermesi nedeniyle bulanık mantık tekniği kullanılmıştır. Modelde, trafik hacmi, taşıt kuyruk uzunluğu ve kırmızı sinyal süresi dikkate alınmıştır. Bulanık mantık gecikme modeli arazi çalışmasından elde edilen değerler kullanılarak süregelen bazı yaklaşımlar ile karşılaştırılmış ve başarılı sonuçlar elde edilmiştir. Özellikle doygun ve doygun üstü trafik koşulları olarak adlandırılan talebin kapasiteye çok yakın veya üzerinde olduğu durumlarda, gerçek gecikme değerinden oldukça farklı sonuçlar verdiği anlaşılmıştır. Çalışma, bulanık mantık gibi esnek ve uyarlanabilir bir modelleme tekniğinin trafikteki gecikme tahmininde uygulanabilirliğini göstermiştir [4]. 
Akçelik 2005 yılında, kavşak tipi değiş̧ikliğinin kavşak kapasitesine etkisini inceleyen bir çalışma yapmıştır. Çalışmada, Avustralya Melbourne' de bulunan iki dönel kavşağın, kavşaktaki gerçek trafik hacimlerini ve kavşağın gerçek geometrik özelliklerini ele alarak, dönel kavşak ve kısmi denetimli sinyalize dönel kavşak olarak analizini gerçekleştirmiştir. Analizler sonucunda, söz konusu kavşağın kısmi denetimli sinyalize dönel kavşak olarak tasarlanması durumunda kavşak performansının, dönel kavşak olarak yapılan tasarımın kavşak performansına nazaran daha iyi olduğu sonucuna ulaşmıştır. Sonuçlar, her iki kavşakta da, kısmi denetimli sinyalize dönel kavşak uygulaması ile kavşaktaki ortalama taşı gecikmesinin ciddi oranda azaldığını ortaya koymaktadır. Aynı şekilde, çalışmalar detaylı olarak incelendiğinde, kısmi denetimli sinyalize dönel kavşak uygulaması ile karbondioksit emisyonu, işletim maliyeti, toplam duruş sayısının da önemli oranda azaldığı görülmüştür [5].

Yıldız tarafından yapılan yüksek lisans tez çalışmasında, kavşak kapasitesi, kavşak güvenliği ve maliyeti parametreleri ile birlikte ele alınmıştır. Çalışmada kavşakların seçiminde yol gösterecek bir model geliştirilerek, bu model yine tez kapsamında yapılan bir yazılım ile desteklenmiştir. Modeli oluşturan bilgisayar yazılımı ile birlikte kavşak tipi belirlenmesi çalışması maliyet ve güvenlik parametreleri açısından optimize edilmiştir. Sonuç olarak bir kapasite, güvenlik ve maliyet modeli oluşturularak bu model bir yazılım olarak bilgisayar ortamına taşınmış ve modelde, kavşaklar kapasite ve güvenlik açılarından ayrı ayrı değerlendirilip çıkan sonuca göre de maliyet açısından kavşağın yapıma elverişli olup olmadığı incelenmiştir [6]. Kavşak kapasitesi ve güvenliğini bir arada alan başka bir çalışma da Yüksel tarafından yine yüksek lisans tezi olarak yapılmıştır. Çalışmada, kavşakların kapasite ve güvenlik parametrelerini esas alan karar verme sürecini değerlendirmiş ve genel hatlarıyla geometrileri, çalışma prensipleri, tasarım esasları, kapasite ve güvenlik performansları tanımlanmıştır [7].

Trafik akımının kompozisyonu da, kavşak performansını etkileyen en önemli etkenlerden birisidir. Kavşağı kullanan ağır taşıt sayısı arttıkça, kavşak performansının önemli ölçüde azaldığı bilinmektedir. Tanyel, Çalışkanelli, Aydın ve Utku, İzmir Türkiye' de 5 farklı dönel kavşaktaki farklı trafik durumlarını inceleyerek, minibüslerin ve farklı tip otobüslerin (körüklü, körüksüz) dönel kavşak performansı üzerindeki etkilerini araştırmışlardır. Araştırmalar, daha detaylı bilgi edinmek için, ana yol ve yan yol ayrı ayrı dikkate alınarak gerçekleştirilmiştir. Çalışma sonucunda, ana akımdaki ortalama hızın düşük olması durumunda ağır taşıt etkisinin daha fazla görüldüğü belirtilmiştir [8].

Yang, Li ve Xue; modern dönel kavşaklar için, dönel kavşakta trafik ve güvenlik sorununa neden olan örülme bölgelerini ve karışıklık noktalarını elimine eden yeni bir sinyal kontrol metodu önermişlerdir. Çalışmada, sirkülasyon şeridindeki kuyruk uzunluğu göz önünde bulundurularak her bir trafik akımı için yeşil süre ve devre süresi hesabı sağlanmıştır. Dönel kavşağın performansını değerlendirmek amacıyla, önemli performans parametreleri olan kapasite ve gecikme de formüle edilmiştir. Bu yeni trafik kontrolü, Xiamen-Çin' de bulunan bir dönel kavşaktaki ciddi trafik tıkanıklığ 1 sorunlarını çözmek için kullanılmış ve başarıyla sonuçlanmıştır. Çalışma kapsamında yapılan önce ve sonra analizleri, kavşak işletiminde ciddi boyutta iyileşme olduğunu göstermiştir. Uygulanan yöntem ile her bir taşıtın ortalama gecikmesi yaklaşık 20 saniye azalmış, kapasite ise düz giden akımlar için \%118 artarken, sola dönen akımlar için ise \% 96 artarak, ortalamada \%72,1 artış göstermiştir [9]. Sinyalizasyon 
düzenlemesiyle kavşak kapasitesini artırmayı amaçlayan başka bir çalışma Maher tarafından yapılmıştır. Bu çalışmada, işletim karmaşıklığı problemlerinin çözümü için geliştirilen cross-entropy metodunu kullanarak sinyalize dönel kavşaklarda sinyal süresi optimizasyonu için yeni bir yöntem geliştirmiştir. Çalışmada, süre setlerinin performansı bir deterministik mikroskobik trafik akım modeli olan, hücre iletim modeli kullanılarak değerlendirilmiştir. Çalışmalar sonucunda, cross-entropy metodunun küresel optimizasyon problemlerini çözmek için yararlı (kullanılabilir) bir yöntem olduğu sonucuna ulaşılmıştır [10]. Ma, Liu, Head ve Yang ise sinyalize kavşaklar için süre ve şerit işaretlemelerinin aynı anda belirlenebildiği bütünleşik optimizasyon modeli geliştirmeyi amaçlamışlardır. Araştırmacılar, sinyalize kavşak işletimini optimize etmek için, kapasite maksimizasyonunu, devre süresi uzunluğu minimizasyonunu ve gecikme minimizasyonunu formüle etmişlerdir. Çalışma sonucunda elde edilen sonuçlar ve hassaslık analizi sonuçları, kapasite optimizasyonu için geliştirilen modelin etkin olduğunu göstermiştir [11].

Mandavilli, Rys ve Russell, sinyalize kavşakların, belli durumlarda taşıt trafiğinin hızını azalttığını hatta bazı durumlarda trafiğin durmasına yol açtığını ve bu durumun taşıt emisyonunda önemli düzeyde artışa sebep olduğunu belirtmişlerdir. Araştırmacılar, Amerika' da ki birkaç modern dönel kavşakta yaptıkları gözlemler sonucunda, dönel kavşakların trafik akımını iyileştirme etkisine sahip olduğunu, bunun yanı sıra kavşaktaki taşıtların boşa harcadığı zamanı azalttığını ve buna bağlı olarak kavşaktaki yakıt tüketimi ve taşıt emisyonunun da azaldığını açıklamışlardır. Çalışma kapsamında, sinyalize kavşağın kaldırılarak yerine modern dönel kavşağın yerleştirildiği altı farklı bölge dikkate alınmış ve bu bölgelerdeki trafik verileri kullanılmıştır. Sinyalize kavşaklar ve modern dönel kavşaklar karbondioksit, nitrik oksit, karbon monoksit, hidrokarbon emisyon parametreleri dikkate alınarak birbirleri ile istatistiksel olarak karşılaştırılmış, karşılaştırmaların sonucunda modern dönel kavşakların taşıt emisyonunu azaltmak için iyi bir alternatif kavşak olarak kullanılabileceği sonucuna ulaşılmıştır. Yapılan çalışma modern dönel kavşakların çevre dostu olduğunu da açıkça ortaya koymuştur [12]. Sisiopiku ve Oh tarafından yapılan benzer bir çalışmada, dönel kavşaklarda uygulanan yöntemlerini performans açısından birbirleri ile karşılaştırmıştır. Çalışma sonucunda, yüksek düzeyde düz giden veya sola dönen trafik hacimlerinin mevcut olduğu kavşaklar için, dönel kavşağın en iyi alternatif tasarım olduğu sonucuna ulaşmışlardır. Ayrıca sola dönüş oranı fark etmeksizin, aynı trafik durumları için, dönel kavşak kapasitesinin sinyalize kavşak kapasitesinden daha fazla olduğunu belirtmişlerdir. Çalışma sonucunda, dönel kavşakların sinyalize kavşaklara kıyasla daha etkin olduğu durumlar hakkında araştırmacılara öneriler sunmuşlardır [13].

Kavşaklar için en önemli hususlardan birisi de kavşağın hizmet düzeyidir. Hizmet düzeyi yüksek olan kavşaklarda trafik akımları, hareketlerine daha rahat ve konforlu şekilde devam edebilecek, çok fazla gecikme olmayacağı için seyahat süreleri kısalacaktır. Johnnie, Ahmed ve Iman, yaptıkları çalışmada, sinyalize dönel kavşaklardaki ve dönel kavşaklardaki hizmet düzeyini belirlemeyi amaçlamışlardır. Bu çalışmada, kavşak performans parametresi olarak ortalama gecikme kullanılmıştır. Analizler sonucunda, dönel kavşaktaki trafik sinyallerinin kapatıldığı durumda kavşak tıkanması ve çakışmalarda önemli ölçüde azalma olduğu görülmüş, dönel kavşak uygulaması ile hizmet düzeyinin az da olsa arttırılabildiği sonucuna ulaşılmıştır. Çalışma, sinyalize dönel kavşakların kavşak tıkanmasında ve taşıt çakışmasında önemli bir etkiye sahip olduğunu açıkça ortaya koymuştur [14]. 


\section{Kent içi kavşak puanlama yöntemi oluşturulması}

Bugüne kadar yapılan çalışmalarda şehir içi kavşakların trafik güvenliği açısından değerlendirilmelerinde soyut ifadeler kullanılmıştır. Kavşak güvenlik parametrelerinin bir bütün olarak değerlendirilebilmesi ve kavşakların trafik güvenliği açısından birbiriyle kıyaslanabilmesi için bu soyut değerlendirmeler, sağlıklı ve yeterli olmamaktadır. $\mathrm{Bu}$ nedenle yapılan bu çalışmada şehir içi kavşakların mevcut durumlarını sayısal olarak ortaya koyan bir yöntem geliştirilmesi hedeflenmiştir. Bu yöntemle şehir içi kavşaklarda yaşanan problemler tespit edilecek, puanlama sonuçlarına göre öncelikler belirlenebilecek, doğru ve etkin müdahale yöntemleri geliştirilebilecektir.

Bir kavşağın etkinliği ve işlevselliği değerlendirilirken güvenliği kadar kapasitesi de önem taşımaktadır. Bu nedenle oluşturulan kavşak puanlama yönteminde kavşağın kapasitesi de değerlendirilecek ve sayısallaştırılacaktır.

Oluşturulan kavşak değerlendirme puantaj tablosu dokuz kısımdan oluşmaktadır. Bunlar Tablo 1' de özetlenmiştir.

Tablo 1. Kavşak parametreleri.

\begin{tabular}{|l|l|}
\hline Kavşak parametreleri & Puan \\
\hline Kavşak kapasite analizi & 20 \\
\hline Trafik işaret ve levhaları & 10 \\
\hline Yönlendirme levhaları & 10 \\
\hline Kavşak geometrisi & 10 \\
\hline Kaplama & 10 \\
\hline Sinyalizasyon sistemi & 10 \\
\hline Yaya geçitleri görüşünü & 10 \\
\hline $\begin{array}{l}\text { Sürücü } \\
\text { engelleyen unsurlar }\end{array}$ & 10 \\
\hline Kavşak denetimi & 10 \\
\hline
\end{tabular}

Kavşak değerlendirmeleri; kavşak kapasite analizi "20" puan, son 8 madde ise "10"ar puan olmak üzere "100" puan üzerinden yapılacaktır. Yani yapılan bu sayısallaştırma sonucu elde edilen puantaj tablosunda ideal bir şehir içi kavşak "100" tam puan alacaktır.

Kavşak değerlendirme puantaj tablosundaki 1. madde olan kavşak kapasite analizi yapılırken Şekil 1.'deki grafik kullanılacaktır. Çalışmada hızlı değerlendirme yöntemi kullanıldığı için yapılacak kapasite analizinde bu grafik kullanılmakla birlikte daha detaylı çalışmalarda uygun kapasite ve başarım (gecikme v.b.) analiz yöntemleri yapılması önerilmektedir. 


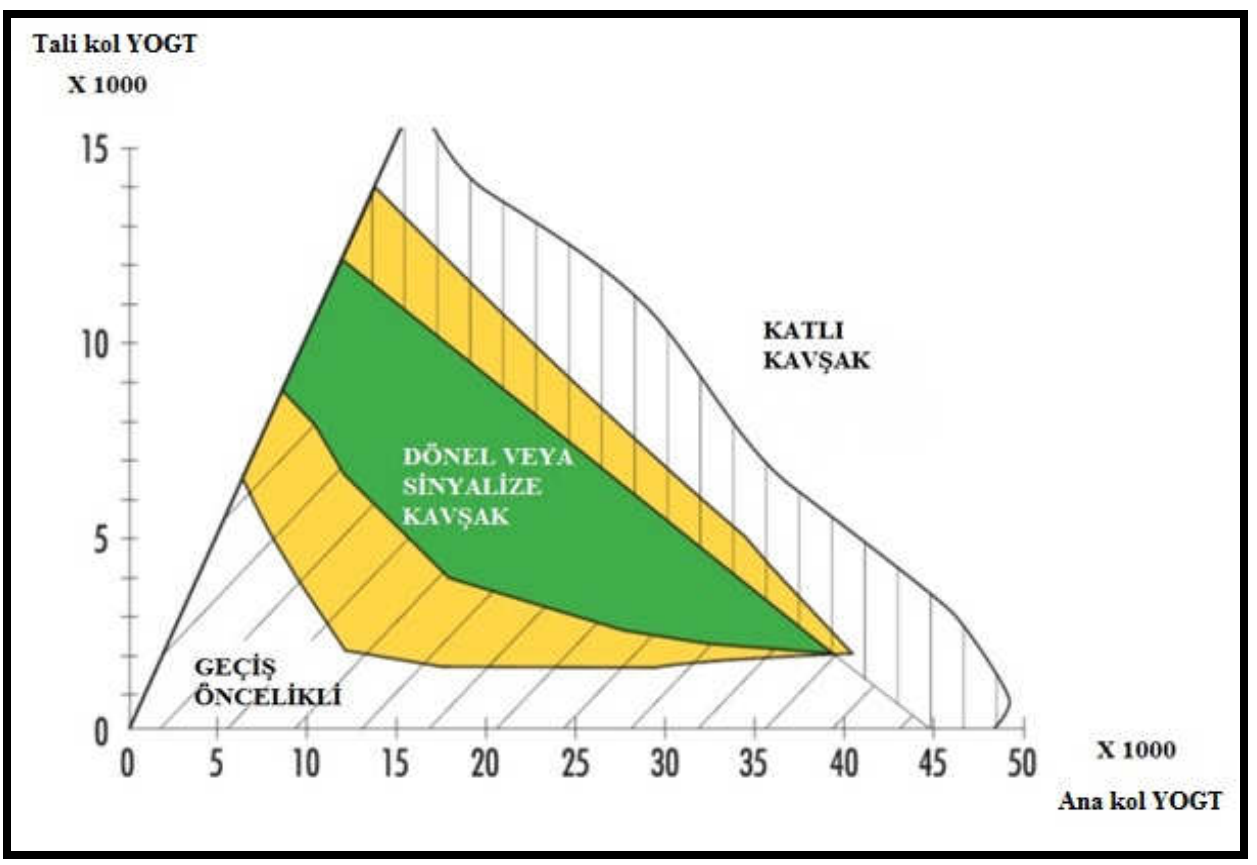

Şekil 1. Kavşak kapasitesi değerlendirme grafiği [17].

Kavşaklarda yapılan pik saat taşıt yoğunluğu sayımı sonuçları;

YOGT (Şehir içi Yollarda)=Mzirve (Maksimum saatlik trafik)/0,10 formülü kullanılarak, yıllık ortalama günlük trafik (YOGT) değerleri bulunacaktır [15].

Ana kol ve tali kola ait YOGT değerleri Şekil 1.'deki grafikte okunacak ve taşıt yoğunluklarına karşılık gelen kavşak tipi bulunacaktır. Eğer kavşağın mevcut tipi grafikte tespit edilen kavşak tipinden daha yüksek kapasitedeki bir tipte veya aynı kavşak tipinde ise, söz konusu kavşak, kapasite açısından '20" tam puan alacaktır. Tam tersi bir durumda ise yani, grafikte belirlenen kavşak tipi mevcut kavşak tipinden daha yüksek kapasitede bir kavşak tipinde ise " 0 "' puan alacaktır.

Son sekiz madde ise detaylandırılarak, güvenlik parametreleri puantaj tablosu oluşturulmuştur. Hızlı değerlendirme yöntemi gereğince, her bir parametreye durumuna göre "0", "1" veya " 2 " puan verilmiştir. "0" puan parametrenin kavşakta olmasının istenmediği duruma; "2" puan ise ideal bir şehir içi kavşakta olması beklenen duruma karşılık gelmektedir. "1" puan ise değerlendirme aralığ geniş olan parametrelerde kullanılmakta olup; ne tamamen yok denilebilecek, ne de tam anlamiyla istenileni karşılıyor denilebilecek durumlara karşılık gelmektedir. Her bir değerlendirme grubu kendi içinde puanlanmış, sonrasında "10" puana göre oranlanmıştır.

Şehir içi kavşak güvenlik parametrelerinin etüt yapılırken hangi durumlarda kaç puan alacağını gösteren puantaj tablosunun detayı Tablo 2'de verilmiştir. Tablonun "kavşak geometrisi” bölümünde yer alan kriterler (kollar arası açı, göbek çapı uygunluğu, vb.) Tür Standartları Enstitüsü, kavşak standart esaslarına göre belirlenmiştir (TS 11937, TS 11784, TS 8252) 
Tablo 2. Güvenlik parametreleri puantaj tablosu.

\begin{tabular}{|c|c|c|}
\hline \multicolumn{3}{|l|}{ TRAFIK İŞARET VE LEVHALARI } \\
\hline \multicolumn{3}{|l|}{ YATAY } \\
\hline \multirow{3}{*}{ Şerit çizgilerinin kalitesi } & Görünür & 2 \\
\hline & Silik & 1 \\
\hline & Yok & 0 \\
\hline \multirow{3}{*}{ Kavşak içi yönlendirme işaretleri } & Görünür & 2 \\
\hline & Silik & 1 \\
\hline & Yok & 0 \\
\hline \multirow{2}{*}{ İkaz işaretleri (hız limitleri) } & Var & 2 \\
\hline & Yok & 0 \\
\hline \multicolumn{3}{|l|}{ DÜŞEY } \\
\hline \multirow{3}{*}{ Kavşak yaklaşım levhası } & Uygun yerde & 2 \\
\hline & Uygun yerde değil & 1 \\
\hline & Yok & 0 \\
\hline \multirow{2}{*}{ Kavşak içi yönlendirme } & Var & 2 \\
\hline & Yok & 0 \\
\hline \multicolumn{3}{|l|}{ YÖNLENDİRME LEVHALARI } \\
\hline \multirow{3}{*}{ Ön bilgi levhası mevcut mu? } & Uygun yerde & 2 \\
\hline & Uygun yerde değil & 1 \\
\hline & Yok & 0 \\
\hline \multirow{3}{*}{ Baş üstü levhası mevcut mu? } & Yeterli & 2 \\
\hline & Yetersiz & 1 \\
\hline & Yok & 0 \\
\hline \multirow{2}{*}{ Yol ayrım levhsı mevcut mu? } & Var & 2 \\
\hline & Yok & 0 \\
\hline \multirow{2}{*}{ Kavşak içi sistem levhası mevcut mu? } & Var & 2 \\
\hline & Yok & 0 \\
\hline \multicolumn{3}{|l|}{ KAVŞAK GEOMETRISİ } \\
\hline \multirow{3}{*}{ Kollar arası açı } & Uygun & 2 \\
\hline & Kabul edilebilir & 1 \\
\hline & Kabul edilemez & 0 \\
\hline \multirow{2}{*}{ Ada çapı uygunluğu } & Uygun & 2 \\
\hline & Uygun değil & 0 \\
\hline \multirow{3}{*}{ Karşı1ıklı kollar arası açı } & Uygun & 2 \\
\hline & Kabul edilebilir & 1 \\
\hline & Kabul edilemez & 0 \\
\hline \multirow{2}{*}{ Depolama alanları yeterliliği } & Yeterli & 2 \\
\hline & Yetersiz & 0 \\
\hline \multirow{2}{*}{ Kavşağa giren ve çıkan şerit sayıları eşit mi? } & Eşit & 2 \\
\hline & Eşit değil & 0 \\
\hline \multirow{2}{*}{ Kavşağa komşu parsellerden (arazilerden) kavşak içerisine giriş-çıkış var mı? } & Var & 0 \\
\hline & Yok & 2 \\
\hline \multirow{2}{*}{ Kavşağa girmeden dönüş adaları mevcut mu? } & Var & 2 \\
\hline & Yok & 0 \\
\hline
\end{tabular}


Tablo 2. (Devam1).

\begin{tabular}{|c|c|c|}
\hline \multirow{2}{*}{$\begin{array}{l}\text { Yaya ve taşı yolu arasında ayrımı sağlayan yapı elemanı bütünlük sağlıyor } \\
\text { mu? }\end{array}$} & Evet & 2 \\
\hline & Hayır & 0 \\
\hline \multirow{3}{*}{ Kollar arası kot farkı uygun mu? } & Uygun & 2 \\
\hline & Uygun değil & 0 \\
\hline & Kabul edilebilir & 1 \\
\hline \multicolumn{3}{|l|}{ KAPLAMA } \\
\hline \multirow{2}{*}{ Yolun drenaj durumu uygun mu? } & Evet & 2 \\
\hline & Hayır & 0 \\
\hline \multirow{2}{*}{ Çukur, tümsek, göçük, vb. yol bozuklukları var mı? } & Evet & 0 \\
\hline & Hayır & 2 \\
\hline \multirow{2}{*}{ Kaplama kavşak boyunca bütünlük sağlıyor mu? } & Evet & 2 \\
\hline & Hayır & 0 \\
\hline \multicolumn{3}{|l|}{ SINYALIZASYON SISTEMI } \\
\hline \multicolumn{2}{|l|}{ Trafik Uyarmalı Sinyalizasyon Sistemi } & 2 \\
\hline \multicolumn{2}{|l|}{ Yaya Uyarmalı Sinyalizasyon Sistemi } & 1 \\
\hline \multicolumn{2}{|l|}{ El ile Kumandalı Sinyalizasyon Sistemi } & 0 \\
\hline \multicolumn{3}{|l|}{ YAYA GEÇITLERII } \\
\hline \multirow{2}{*}{ Engelli rampası mevcut mu? } & Var & 2 \\
\hline & Yok & 0 \\
\hline \multirow{3}{*}{ Yaya geçidi çizgileri mevcut mu? } & Görünür & 2 \\
\hline & Silik & 1 \\
\hline & Yok & 0 \\
\hline \multirow{2}{*}{ Yaya geçidinin yeri uygun mu? } & Uygun & 2 \\
\hline & Uygun değil & 0 \\
\hline \multirow{2}{*}{ Yaya yolu kaplaması bütünlük sağlıyor mu? } & Uygun & 2 \\
\hline & Uygun değil & 0 \\
\hline \multirow{2}{*}{ Yaya geçişini engelleyen unsur var mı? } & Var & 0 \\
\hline & Yok & 2 \\
\hline \multicolumn{3}{|l|}{ SÜRÜCÜ GÖRÜŞÜNÜ ENGELLEYEN UNSURLAR } \\
\hline \multirow{2}{*}{ Sinyal lambası, levha vs'nin görüşünü kapatan unsur var mı? } & Var & 0 \\
\hline & Yok & 2 \\
\hline \multirow{3}{*}{ Görüşü engelleyen reklam panosu var mı? } & Işıklı & 0 \\
\hline & Işıksız & 1 \\
\hline & Yok & 2 \\
\hline \multirow{2}{*}{ Görüşü engelleyen havuz, fıskiye, vs. var mı? } & Var & 0 \\
\hline & Yok & 2 \\
\hline \multirow{3}{*}{ Kavşak içi aydınlatma mevcut mu? } & Yeterli & 2 \\
\hline & Yetersiz & 1 \\
\hline & Yok & 0 \\
\hline \multicolumn{3}{|l|}{ MBS-EDS } \\
\hline \multirow{2}{*}{ Mobil Elektronik Sistem Entegrasyonu (MBS) var mı? } & Var & 2 \\
\hline & Yok & 0 \\
\hline \multirow{2}{*}{ Elektronik Denetleme Sistemi (EDS) var mı? } & Var & 2 \\
\hline & Yok & 0 \\
\hline
\end{tabular}




\subsection{Alan çalışması}

Şehir içi kavşak puanlama yönteminin işlevselliğini denemek amacıyla, Ankara Kentinde yer alan üç adet sinyalize kavşakta, pilot çalışma yapılmış ve bu kavşakların yeterlilik durumu sayısal olarak ortaya konulmuştur. Alan çalışmasında değerlendirme de kullanılan veriler, Ankara Büyükşehir Belediyesi Ulaşım Dairesi Başkanlığı teknik ekibi ve çalışmanın yazarlarının da içinde bulunduğu 6 kişilik bir grup tarafından yerinde ölçüm ve gözlem metodu ile elde edilmiştir.

Kavşaklar seçilirken günlük nüfus hareketlerinin yoğun olduğu, kentin merkezi, yerleşim alanlarına yakın olan ve uzun süredir mevcut haliyle kullanılan kavşaklar tercih edilmiştir. Seçilen kavşaklar aşağıda numaralandırılmış ve Şekil 2,3 ve 4'de kavşak görüntüleri ve pik saat taşıt yoğunlukları verilmiştir.

1) Tıp Fakültesi Caddesi - Münzeviler Caddesi Kesişimi Kavşağı (Şekil 2)

2) Mareşal Fevzi Çakmak Caddesi - Akdeniz Caddesi Kesişimi Kavşağı (Anıttepe Kavşağı) (Şekil 3).

3) Talat Paşa Bulvarı - Cemal Gürsel Caddesi Kesişimi Kavşağı (Dikimevi Kavşağı) (Şekil 4).
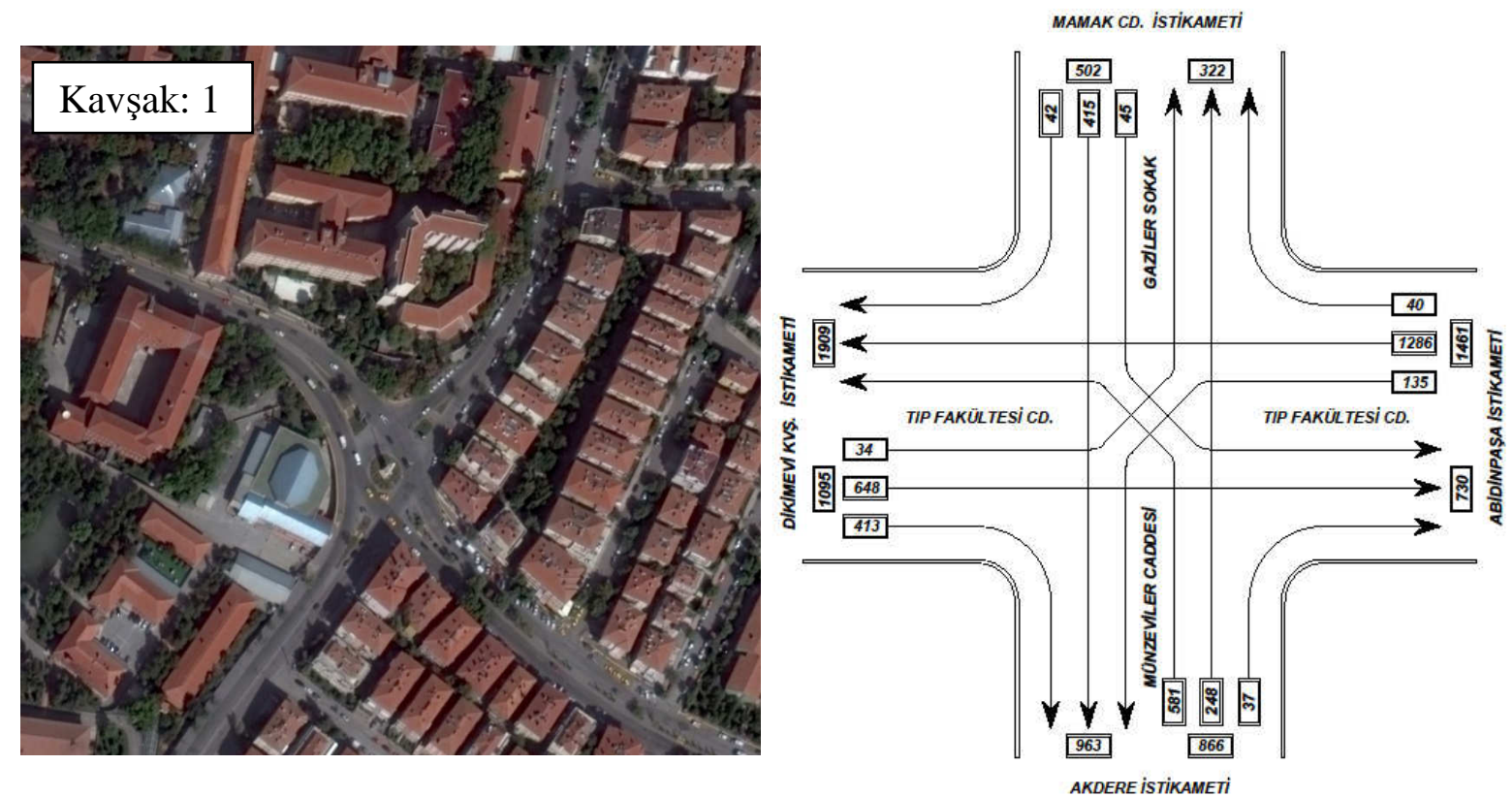

Şekil 2. Tıp Fakültesi Caddesi - Münzeviler Caddesi Kesişimi Kavşağı. 

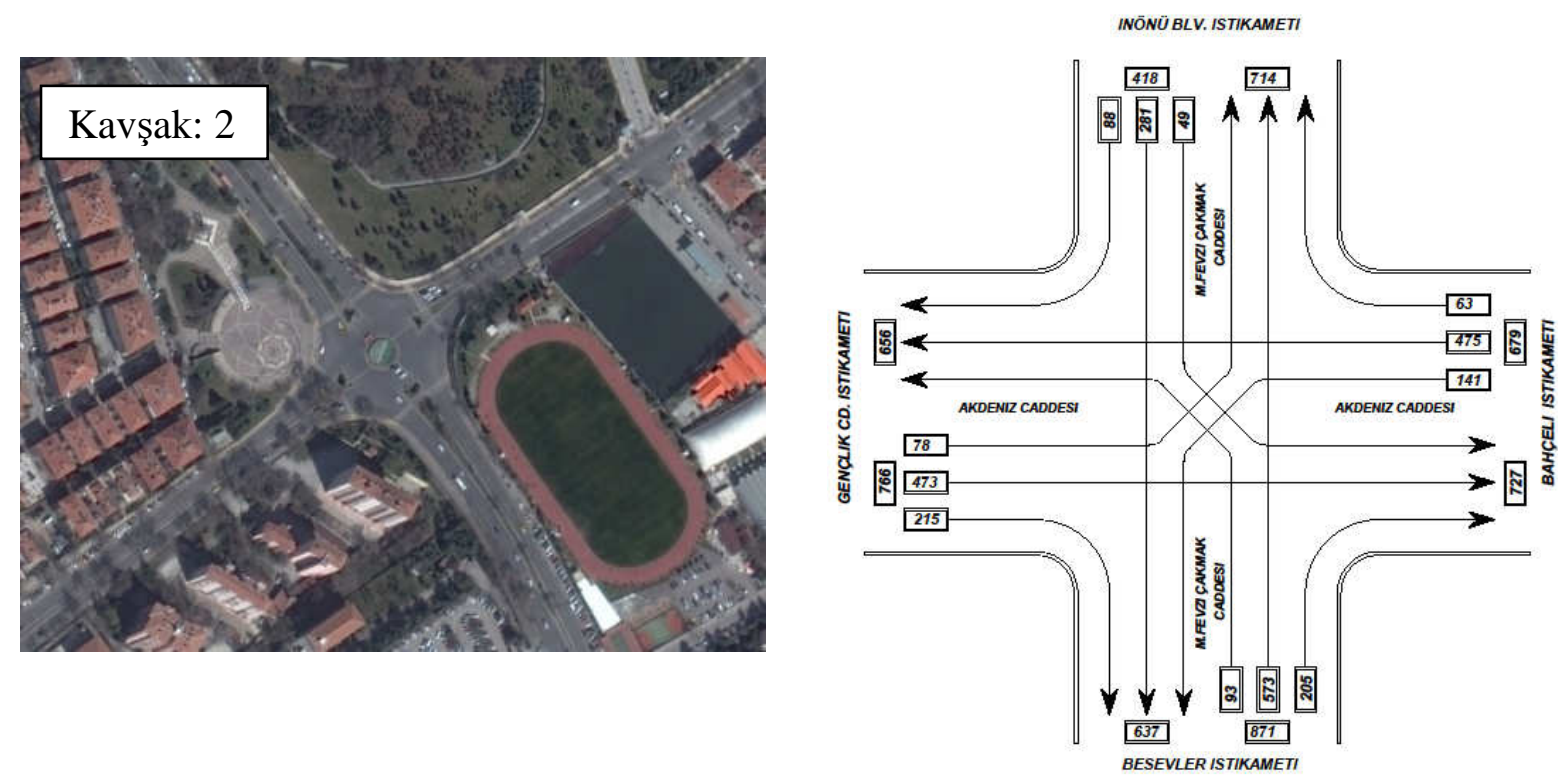

Şekil 3. Anıttepe Kavşağı.
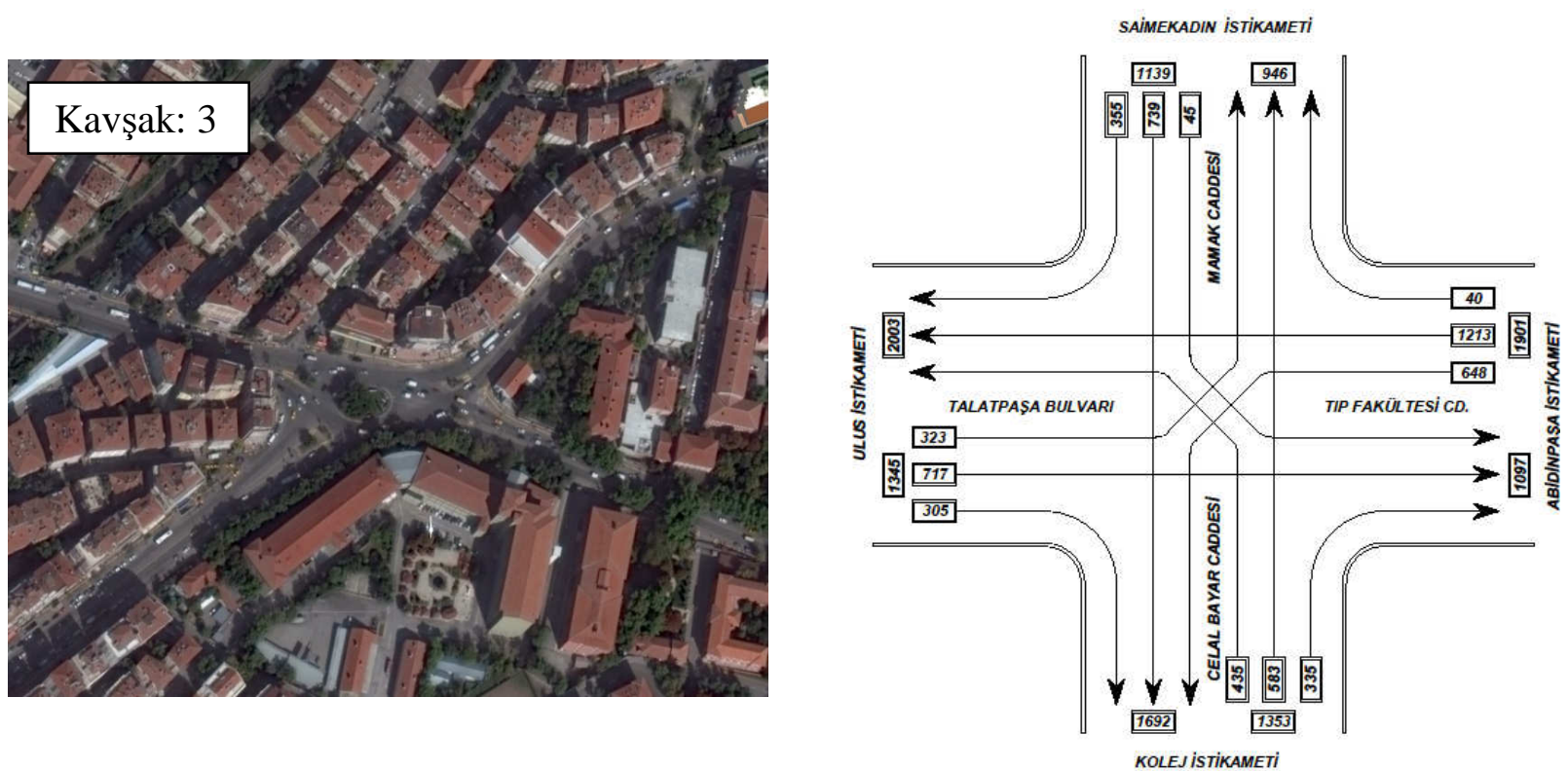

Şekil 4. Dikimevi Kavşă̆1.

Yapılan etüt çalışmalarında elde edilen sonuçlar karşılaştırmalı biçimde Tablo 3'de yer almaktadır. 
Tablo 3. Değerlendirilen kavşaklardan elde edilen puanlar.

\begin{tabular}{|l|c|c|c|}
\hline & Kavşak: 1 & Kavşak: 2 & Kavşak: 3 \\
\hline $\begin{array}{l}\text { KAVŞAK } \\
\text { KAPASiTE } \\
\text { ANALIZİ }\end{array}$ & 20,00 & 20,00 & 0,00 \\
\hline $\begin{array}{l}\text { TRAFIK IŞARET } \\
\text { VE LEVHALARI }\end{array}$ & 3,00 & 6,00 & 2,00 \\
\hline $\begin{array}{l}\text { YÖNLENDIRME } \\
\text { LEVHALARI }\end{array}$ & 2,50 & 5,00 & 2,50 \\
\hline $\begin{array}{l}\text { KAVŞAK } \\
\text { GEOMETRiSI }\end{array}$ & 7,22 & 8,89 & 0,56 \\
\hline KAPLAMA & 3,33 & 6,67 & 0,00 \\
\hline $\begin{array}{l}\text { SiNYALİASYON } \\
\text { SiSTEMİ }\end{array}$ & 0,00 & 0,00 & 0,00 \\
\hline $\begin{array}{l}\text { YAYA } \\
\text { GEÇITLERI }\end{array}$ & 7,00 & 10,00 & 3,00 \\
\hline $\begin{array}{l}\text { SÜRÜCÜ } \\
\text { GÖRÜŞÜNÜ } \\
\text { ENGELLEYEN } \\
\text { UNSURLAR }\end{array}$ & 5,00 & 5,00 & 1,25 \\
\hline $\begin{array}{l}\text { KAVŞAK } \\
\text { DENETIMİ }\end{array}$ & 5,00 & 5,00 & 10,00 \\
\hline $\begin{array}{l}\text { GENEL } \\
\text { TOPLAM }\end{array}$ & $\mathbf{5 3 , 0 5}$ & $\mathbf{6 6 , 5 6}$ & $\mathbf{1 9 , 3 1}$ \\
\hline
\end{tabular}

İncelenen üç kavşak arasında, 3 numaralı kavşağın en düşük puan alan, yani en yetersiz kavşak olduğu görülmektedir. Bu kavşağın diğer iki kavşaktan yetersiz olması ve 50 puanın altında kalmasının başlıca sebepleri;

- Kavşakta sürücü görüşünü engelleyen birden fazla obje bulunması,

- Yaya geçidinin yerinin, kaplamasının uygun olmaması ve yaya geçidi çizgilerinin bulunmaması,

- Kaplamada bozukluklar olması ve drenaj sisteminin olmaması,

- Kavşak geometrisinin kabul edilebilir standartların dişında olması,

- Kavşağın mevcut kapasitesinin yetersiz olması olarak özetlenebilir.

İncelenen diğer iki kavşakta kapasite mevcut haliyle yeterli olmasına rağmen 1 numaralı kavşaktaki trafik işaret ve levhaları ile yönlendirme levhalarında bariz şekilde eksiklikler bulunması ve kaplama bozuklukları kavşağın daha düşük puan almasına neden olmuştur.

Ayrıca sinyalizasyon sisteminin el ile kumandalı olması, yatay trafik işaretlerinde şerit çizgilerin dışında bir uygulama olmaması ve kavşak drenajına yönelik bir imalatın bulunmaması incelenen her üç kavşaktaki genel eksikliklerdir.

$\mathrm{Bu}$ sayısal değerlendirme sisteminin kentteki tüm sinyalize kavşaklara uygulanıp ona göre bir acil müdahale sıralaması yapılması çok daha anlamlı olmakla beraber, örnek teşkil etmesi açısından "trafik işaret ve levhaları" parametresi incelenen üç kavşak için analiz edilmişstir (Tablo 4). 
Tablo 4. Trafik işaret ve levhaları parametresi.

\begin{tabular}{|c|c|c|c|c|}
\hline \multicolumn{5}{|c|}{ TRAFIK ISSARET VE LEVHALARI } \\
\hline \multicolumn{2}{|l|}{ YATAY } & Kavşak : 1 & Kavşak : 2 & Kavşak : 3 \\
\hline \multirow{3}{*}{ Şerit Çizgileri } & Görünür & & 2.00 & \\
\hline & Silik & 1.00 & & \\
\hline & Yok & & & 0.00 \\
\hline \multirow{3}{*}{$\begin{array}{l}\text { Kavşak içi } \\
\text { yönlendirme oklar1 }\end{array}$} & Görünür & & & \\
\hline & Silik & & & \\
\hline & Yok & 0.00 & $\mathbf{0 . 0 0}$ & 0.00 \\
\hline \multirow{2}{*}{$\begin{array}{l}\text { İkaz işaretleri (hız } \\
\text { limitleri) }\end{array}$} & Var & & & \\
\hline & Yok & 0.00 & $\mathbf{0 . 0 0}$ & 0.00 \\
\hline \multicolumn{5}{|l|}{ DÜŞEY } \\
\hline \multirow{3}{*}{$\begin{array}{l}\text { Kavşak yaklaşım } \\
\text { levhası }\end{array}$} & Uygun yerde & & 2.00 & \\
\hline & $\begin{array}{l}\begin{array}{l}\text { Uygun yerde } \\
\text { değil }\end{array} \\
\end{array}$ & & & \\
\hline & Yok & 0.00 & & 0.00 \\
\hline \multirow{4}{*}{$\begin{array}{l}\text { Kavşak içi } \\
\text { yönlendirme }\end{array}$} & Var & 2.00 & 2.00 & 2.00 \\
\hline & Yok & & & \\
\hline & Toplam & 3.00 & 6.00 & 2.00 \\
\hline & \begin{tabular}{|c|}
$\% 10 ' a$ \\
Karşılık Gelen \\
Toplam \\
\end{tabular} & 3.00 & 6.00 & 2.00 \\
\hline
\end{tabular}

Tablodaki verilere göre yerel yönetim tarafından kent genelinde "şerit çizgileri”" çizim/bakım işi yapılmak istendiğinde; bu üç kavşak için öncelik sırası 3-1-2 şeklinde olacaktır. Yine düşey işaretleme çalışması yapıldığında 2 nolu kavşak liste dışı birakılacaktır.

\section{Sonuç ve öneriler}

Kentlerde nüfusun artması, hızla gelişen teknoloji ve artan araç sayısı, ulaşım talebindeki artışı da beraberinde getirmektedir. Günümüzde özellikle büyük kentlerde ciddi trafik sorunları yaşanmaktadır. Bu sorunların yaşandığı başlıca yerler ise, kentsel ulaşımın kilit noktaları olan kavşaklardır. Kavşaklar hem trafik gecikmelerinin hem de trafik kazalarının en fazla yaşandığı kentsel alanlardır. Bu nedenle, şehir içi kavşaklarda gerek güvenlik gerekse kapasite açısından düzenli ve sistemli iyileştirmeler yapılması büyük önem taşımaktadır.

$\mathrm{Bu}$ çalışmada, hizmet veren bir kavşağın değerlendirilebilmesi için bir puantaj tablosu oluşturulmuştur. Oluşturulan kavşak değerlendirme puantaj tablosunda 9 ana parametre ve 35 alt parametre bulunmaktadır. İlk parametre olan "kavşak kapasite analizi” için kavşak da pik saat trafik sayımı yapılıp YOGT değerlerinin hesaplanması, diğer 8 parametre için ise yerinde inceleme ve değerlendirme yapılması gerekmektedir. Yapılan sonuç değerlendirmesi, ideal bir kavşak "100" puan alacak şekilde düzenlenmiştir. İnceleme sonucunda elde edilen puanın ideal bir kavşağa ne kadar uzakta olduğu veya ideal kavşağa ulaşabilmek için hangi parametrelerde düzeltmelere gidilmesi gerektiği konusunda somut veriler sunmaktadır. 
Yerel yönetimlerin görev kapsamına giren şehir içi kavşak düzenlemeleri uygulamaları sırasında bu yöntemin kullanılmasının, iyileştirme çalışmaları için ciddi anlamda veri tabanı oluşturacağı düşünülmektedir. Oluşturulan bu sayısal kavşak bilgilerinin iki şekilde kullanılması önerilmektedir. İlk olarak; “100” puan üzerinden, beklentiye göre daha önceden belirlenmiş bir baraj puanın altında kalan kavşaklar, en düşük puan alan kavşaktan başlamak üzere iyileştirme çalışmalarına tabi tutulabilecektir. İkinci olarak ise; her bir kavşak parametresi ayrı ayrı ve tüm kavşaklar için değerlendirmeye alınabilecektir. Örneğin "Kaplama” parametresi tüm kavşaklar için uygulanır ve en az puan alan kavşaktan en çok puan alan kavşağa doğru sıralanır. Yerel yönetimler kaplama ile ilgili çalışma yapacağı zaman bu sıralamayı bir öncelik tablosu olarak kullanabileceklerdir. Bu sayede maddi kaynaklar da daha etkin kullanılmış olacaktır.

Çalışma kapsamında oluşturulan sayısal değerlendirme sisteminin işlevselliğini denemek amacı ile Ankara kenti içinden üç adet kavşak seçilmiştir. Bu üç kavşakta pik saat trafik sayımları yapılmış, güvenlik parametreleri gözlemlenmiş ve elde edilen bilgiler sayısallaştırılmıştır. Sayısallaştırma sonucu kavşakların almış olduğu toplam puanlar yorumlanmış ve örnek olarak "trafik işaret ve levhaları" parametresi için kavşaklar arasında öncelikli müdahale sıralaması yapılmıştır. Ancak kentsel ulaşım ilkeleri açısından, kavşakları kent bağlamından bağımsız olarak değerlendirmemek ve bir altyapı kararı verilirken kent ulaşım ağının bütününü ele almak gerekmektedir. Bu nedenle çalışmanın, kent ulaşım ağının içinde bulunan tüm sinyalize ana kavşakların bu yöntemle incelenmesi ile en sağlıklı sonucu vereceği düşünülmektedir. Bunların yanında; parametreler veya kavşak sayıları artırılarak analizin kapsamı ve detayının da artırılmaya müsait olması durumu yöntemi geliştirilebilir ve uygulanabilir kılmaktadır

\section{Kaynaklar}

[1] Karayolları Genel Müdürlüğü, Karayolu Tasarımı El Kitabı, 100-120, Ankara, (2005).

[2] Çetin, M., Sinyalize kavşaklarda doygun akım oranının belirlenmesinde yeni bir yaklaşım, Doktora Tezi, Pamukkale Üniversitesi, Fen Bilimleri Enstitüsü, Denizli, (2015).

[3] Murat, Y.Ş., Çakıcı, M., Sinyalize Dönel Kavşaklar için Hesap Yöntemi Önerisi ve Performans Analizi, İnşaat Mühendisleri Odası Teknik Dergisi, 7569-7592, (2016).

[4] Murat Ş., Sinyalize kavşaklardaki taşıt gecikmelerinin bulanık mantık ile modellenmesi, İnşaat Mühendisleri Odası Teknik Dergisi, 3903-3916, (2006).

[5] Akçelik, R. (2005). Capacity and performance analysis of roundabout metering signals. TRB National Roundabout Conference, Vail, Colorado.

[6] Yıldız, D., Kapasite, güvenlik ve maliyet analizi ve geliştirilmesi ile optimize edilmiş kavşak tipini belirleyen program üretilmesi, Yüksek Lisans Tezi, Fen Bilimleri Enstitüsü, Ankara, (2013).

[7] Yüksel, E., Modern dönel kavşakların kapasite ve trafik güvenliği yönünden incelenmesi, Yüksek Lisans Tezi, Fen Bilimleri Enstitüsü, Ankara, (2007).

[8] Tanyel, S., Çalıskanelli, S. P., Aydın, M. M., Utku, S. B., Yuvarlakada kavşaklardaki ağır araç etkisinin incelenmesi, TMMOB İşaat Mühendisleri Odası Teknik Dergisi, 24(4), 6479-6504, (2013). 
[9] Yang, X., Li, X., Xue, K., A New Traffic-Signal Control for Modern Roundabouts: Method and Application, IEEE Transactions on Intelligent Transportation Systems, 5(4), 282-287, (2004).

[10] Maher, M., The Optimization of Signal Settings on a Signalized Roundabout Using the Cross-Entropy Method, Computer-Aided Civil and Infrastructure Engineering, 23(2), 76-85, (2008).

[11] Ma, W., Liu, Y., Head, L., Yang, X., Integrated Optimization of Lane Markings and Timings for Signalized Roundabouts, Transportation Research Part C: Emerging Technologies, 36, 307-323, (2013).

[12] Mandavilli, S., Rys, M. J., Russell, E. R., Environmental Impact of Modern Roundabouts, International Journal of Industrial Ergonomics, 38(2), 135-142, (2008).

[13] Sisiopiku, V., Oh, H., Evaluation of Roundabout Performance Using Sidra, Journal of Transportation Engineering, 127(2), 143-150, (2001).

[14] Johnnie, B. E., Ahmed, A., Iman, A., Extent of Delay and Level of Service at Signalized Roundabout, International Journal of Engineering \& Technology, 2(3), 419-424. (2012).

[15] Özdirim, M., Trafik Mühendisliği 1, Karayolları Genel Müdürlüğü, 309, (1994) 